\title{
Commentary: From little things big things grow
}

\author{
Yaroslav Ivanov, $\mathrm{MD}, \mathrm{PhD},{ }^{\mathrm{a}, \mathrm{b}}$ \\ Edward Buratto, MBBS, PhD, FRACS, a,b,c \\ Antonia Schulz, MD, ${ }^{\mathrm{a}, \mathrm{b}}$ and \\ Igor E. Konstantinov, MD, PhD, FRACS ${ }^{\mathrm{a}, \mathrm{b}, \mathrm{c}, \mathrm{d}}$
}

The rate of implantation of the transvenous automated implantable cardioverter-defibrillators (AICDs) and pacemakers is ever increasing due to the relative simplicity of the implantation and high efficacy. ${ }^{1}$ However, percutaneous implantable devices are not without their shortcomings. ${ }^{1-4}$ As their delivery route is the superior vena cava (SVC) system, not surprisingly most of the complications occur within the deep veins of the upper extremity. ${ }^{2}$ Both venous thrombosis ${ }^{1}$ and stenosis may occur, leading to occlusion. ${ }^{2}$ Most strikingly, the overall prevalence of asymptomatic vein occlusion from a recent meta-analysis study is $8.6 \%{ }^{1}$ Interestingly, even with complete occlusion of SVC, patients may remain free of symptoms, suggesting that a gradual occlusion may allow collaterals to develop.

In the current issue of the Journal, Smith and colleagues ${ }^{5}$ described a patient with complete occlusion of SVC and severely stenotic inferior vena cava (IVC) many years after the AICD implantation. The patient developed the portal hypertension and ascites. The almost-complete occlusion of IVC was treated surgically with IVC patching after other therapeutic and endovascular variants were exhausted. Interestingly, even with complete removal of the AICD system the SVC occlusion remained, yet the patient had complete resolution of the symptoms due to well-developed collaterals. Surgical management of cardiac lesions located

From the ${ }^{\mathrm{a} D e p a r t m e n t}$ of Cardiac Surgery, Royal Children's Hospital; ${ }^{\mathrm{b}}$ Department of Paediatrics, University of Melbourne; ${ }^{c}$ Heart Research Group, Murdoch Children's Research Institute; and ${ }^{\mathrm{d}}$ Melbourne Centre for Cardiovascular Genomics and Regenerative Medicine, Melbourne, Australia.

Disclosures: The authors reported no conflicts of interest.

The Journal policy requires editors and reviewers to disclose conflicts of interest and to decline handling or reviewing manuscripts for which they may have a conflict of interest. The editors and reviewers of this article have no conflicts of interest.

Received for publication Oct 19, 2021; revisions received Oct 19, 2021; accepted for publication Oct 26, 2021; available ahead of print Oct 29, 2021.

Address for reprints: Igor E. Konstantinov, MD, PhD, FRACS, Royal Children's Hospital, Flemington Rd, Parkville, Victoria 3052, Australia (E-mail: igor. konstantinov@rch.org.au).

JTCVS Techniques 2022;11:36

2666-2507

Crown Copyright (C) 2021 Published by Elsevier Inc. on behalf of The American Association for Thoracic Surgery. This is an open access article under the CC BY license (http://creativecommons.org/licenses/by/4.0/).

https://doi.org/10.1016/j.xjtc.2021.10.054

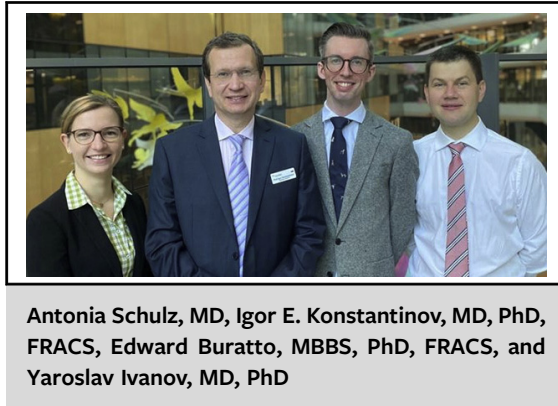

CENTRAL MESSAGE

Inferior vena cava stenosis

following transvenous leads

placement, although avoidable,

may require a complex surgical

approach.

at the right atrium to IVC junction is not always straightforward. ${ }^{6}$ Ironically, this avoidable complication could have been easily prevented by proper placement of the transvenous leads. The best way to deal with complications is to prevent them!

\section{References}

1. Duijzer D, de Winter MA, Nijkeuter M, Tuinenburg AE, Westerink J. Upper extremity deep vein thrombosis and asymptomatic vein occlusion in patients with transvenous leads: a systematic review and meta-analysis. Front Cardiovasc Med. 2021;8:698336.

2. Haghjoo M, Nikoo MH, Fazelifar AF, Alizadeh A, Emkanjoo Z, Sadr-Ameli MA. Predictors of venous obstruction following pacemaker or implantable cardioverter-defibrillator implantation: a contrast venographic study on 100 patients admitted for generator change, lead revision, or device upgrade. EP Europace. 2007;9:328-32.

3. Pavia S, Wilkoff B. The management of surgical complications of pacemaker and implantable cardioverter-defibrillators. Curr Opin Cardiol. 2001;16:66-71.

4. Rozmus G, Daubert JP, Huang DT, Rosero S, Hall B, Francis C. Venous thrombosis and stenosis after implantation of pacemakers and defibrillators. J Interv Card Electrophysiol. 2005;13:9-19.

5. Smith PS, Van Essen GG, Zivin AH, Hayes PG, Ong ES, Lehr EJ. Inferior vena cava-right atrial junction stenosis requiring a multidisciplinary approach to resection and reconstruction. J Thorac Cardiovasc Surg Tech. 2022;11:31-3.

6. Ivanov YY, Konstantinov IE. Commentary: a rare intracaval mass with intracardiac extension: a value of frozen section revisited? J Thorac Cardiovasc Surg. 2019;158:e103-4. 